\section{Of Interest}

\section{New minister for Environment Canada}

The Canadian Forestry Service has acquired a new minister following the defeat at the last election of the Minister of the Environment Jack Davis. The new minister is Madame Jeanne Sauvé. That name is not unfamiliar to many past and present members of the CFS as her husband, Maurice Sauvé, was Minister of Forestry and Rural Development from 1964 until 1968, when he was defeated in the election.

Internal reorganization of Environment Canada continues unabated. Three headquarters DirectorsGeneral and 4 new Regional Directors-General have been appointed that, to quote the news release, "further advances the decentralization of the Environmental Management Service on a regional basis.

"Mr J. P. Bruce has been appointed Director-General, Inland Waters Directorate; Mr A. G. Loughrey is the new Director-General, Canadian Wildlife Service and $\mathrm{Dr}$ G. Fleischmann has been named the DirectorGeneral, Policy and Program Directorate. They join colleagues Dr G. P. Thomas, Director-General, Canadian Forestry Service and Mr R. J. McCormack, Director-General, Lands Directorate as headquarters appointments, in Ottawa.

"The four Regional Director-General appointments are $\operatorname{Dr} M$. Lortie, Quebec Region in Quebec City; Mr L. A. Smithers, Ontario Region in Burlington; Dr A. H. Macpherson, Western and Northern Region in Edmonton and Mr G. B. Armstrong, Pacific and Yukon Region in Vancouver. A Regional DirectorGeneral for the Atlantic Region, who will have his office in Halifax, will be appointed in the near future. The appointments were made following Public Service Commission competitions.

"The Environmental Management Service is organized on a regional basis to meet two major objectives. The first objective is better integration of programs designed for environmental assessments and of other multi-disciplinary projects at both the field and head office levels. The second is the decentralization of line authority to the regions to meet their specific needs.

"Each Regional Director-General is responsible for directing, managing and coordinating the research and operational programs of the four $\mathrm{Di}$ rectorates, Inland Waters, Wildlife, Forestry and Lands, within his Region. Headquarters DirectorsGeneral will exercise line control only over staff assigned to them in the Ottawa area. They will be primarily responsible for general policy and planning national programs and will advise on environmental and resource management programs related to their areas of expertise.

"To facilitate the overall planning and program development for the Environmental Management Service, a new Directorate has been created under the position of Director-General, Policy and Program Development. Dr Fleischmann will also advise the Assistant Deputy Minister on all matters concern- ing the application of federal policy to EMS as a whole as well as on the formulation of EMS policies. The announced organization of the Environmental Management Service has been carried out within existing man years and budgetary allocations."

No doubt there will be more later. The new release concluded with the statement that "the continued national presence and importance of the four agencies that were brought together to form EMS - the Canadian Wildlife Service, Canadian Forestry Service, Inland Waters Directorate and Lands Directorate — will be maintained and indeed strengthened."

Replacing Bud Smithers as Director of the Great Lakes Forest Research Centre at Sault Ste Marie is Jim Cayford, and Jag Maini replaces Marcel Lortie at Quebec.

\section{Full circle}

Fifty-five years after H. R. MacMillan organized the first major export shipments of railway ties from British Columbia to Asia and Europe, a firm associated with the company that bears his name is shipping ties in the opposite direction - from Malaysia to Canada.

MacMillan Jardine Meyer, a company in which MacMillan Bloedel holds a minority interest, has delivered a parcel of 25,000 hardwood railway ties to Canadian National Railways in North Vancouver. One of the H. R. MacMillan Export Company's first large export contracts was a consignment of BCproduced railway ties that were sold to the Nizam of Hyderabad for construction of a railway line in India.

\section{Hybrid aspen outplanted}

The first extensive outplanting of hybrid aspen in Canada was made earlier this year. Twelve thousand seedlings of a largetooth aspen and silver poplar (Populus grandidentata $x$ alba) hybrid variety were planted earlier this year on 77 acres (31 ha) just north of Algonquin Park, Ontario. The variety was produced by the Forest Research Branch of Ontario's Ministry of Natural Resources. It was selected for outstanding performance in small-size test plantations.

The area, an Aspen Site Class 2, had a forest cover of low grade hardwoods and small patches of white pine. It was clear cut by Licensee Canadian Splint and Lumber Co. Ltd. of Pembroke, and prepared using a D-6 bulldozer with Young's teeth attached to the blade. The seedlings were planted at a $12 \times 6 \mathrm{ft}(3.6 \times 1.8 \mathrm{~m})$ spacing by 13 planters during a 9 day period. The average height of the planting stock was 54 inches $(137 \mathrm{~cm})$.

The cost per acre for site preparation was $\$ 31.23$, and for planting $\$ 39.32$. Therefore, the total cost was $\$ 70.55 /$ acre $(\$ 174.33 /$ ha $) . /$ G. R. Swant

The carrying capacity of the average 100-year-old maple tree in Southern Ontario is 246,941 starlings. / Participation filler by $P$. Murtha 


\section{Towards more complete utilization}

A machine that will harvest part of the root system as well as the above ground portion of the tree has been developed by Rome Industries in conjunction with the US Forest Service. The prototype machine has been designed for harvesting southern pines that have a taproot rather than a diffuse root system. Tests will be conducted with trees having the latter type of system. Fibre yield can be increased by as much as $20 \%$ by harvesting the taproot; the increase would be less for a diffuse system.

In essence, the extractor unit grips the base of the stem with knives that cut partially through the stem; a circular cutting edge is forced about 20 inches $(50 \mathrm{~cm})$ into the soil and shears most of the surface laterals; the tree is jacked up several inches and then lifted clear of the ground. The force required to get the shear ring into the soil, especially a dry clay, is much greater than that required to lift the tree out of the ground or to shear the roots themselves. The process of harvesting is only slightly slower than shearing the stem only.

Handling of the material after extraction has not been fully explored yet. Tests have been conducted with transporting the stem plus root as "tree" lengths and pulping in the normal manner (once resistances of the mill manager was overcome). Some dirt clings to the underside of the horizontal roots where they join the taproot. A vibrator may be built into the harvester to reduce the amount of residual soil on the roots. However, the amount present is probably not much more than that acquired by dragging stems through muddy ground.

Tests and modification of the extractor will continue in relation to tree size, different soil conditions and handling matters. There is no expectation that harvesting of the roots will be coming tomorrow but the day after? In 1963 only $30 \%$ of the complete tree was used in the southern States. By 1980 they plan to utilize $60 \%$.

Root shears are being developed by the Canadian Forestry Service for use in species such as black spruce.

\section{Assessment of private forest land}

The Ontario Professional Foresters Association has presented a brief to the Ontario Government concerning the assessment of private forest lands in the province. The OPFA recommends that: a forested land classification for taxation assessment be established; assessment of forested lands be based upon soil capability and geography; and the assessment of forested land be at one half the rate for similar lands in agriculture. (Agricultural lands now receive a provincial rebate of $50 \%$ of the taxes. Forest lands receive less municipal services than agricultural lands.) The Association recommends that the minimum area to qualify be 15 acres (6 ha) of contiguous forest under one ownership.

\section{Urban wildlife}

Only a short time ago an urban wildlife symposium would have been the target for levity, accord- ing to Forest Stearns. His paper is one of many in Wildlife in an Urbanizing Environment, a 182-page illustrated monograph of a symposium held in 1973. Copies of the publication may be obtained at $\$ 3.00$ per copy from the Cooperative Extension Service, Room 213 Stockbridge Hall, University of Massachusetts, Amherst, Mass., USA 01002.

\section{Financial management of forest resources seminar}

A major development for the 1975 Financial Management of Forest Resources Seminar, which will convene in New Orleans, La. at the LePavillon Hotel on January 27-29, is the opening of registration to interested persons outside the category of corporate financial officers, as was the case in 1973. Response from this prestigious but limited group was sufficiently enthusiastic to encourage the presentation of an expanded 1975 Seminar; this year, all those in the industry who have interests in the management of forest resources are cordially invited to attend.

The 1975 Seminar will include presentations from a number of financial experts from both industry and the academic world. These speakers, whose expertise ranges over the entire spectrum of areas relating to forestry financial management, will conduct an intensive program whose central objective is an upgrading of awareness of current techniques on the part of the participants. The potential impact of operations research and financial theory on future practices in timberlands management is enormous, and participants in the Seminar can expect a thorough grounding in basic contemporary techniques upon which to base further inquiry.

As was the case with the preceding seminar, preregistration for the Seminar is required. Fees are anticipated to be $\$ 150$ for members of National TAPPI and $\$ 200$ for nonmembers. Inquiries concerning the 1975 Management of Forest Resources Seminar should be directed to W. B. Manning, TAPPI, One Dunwoody Park, Atlanta, Ga. 30341.

\section{Energy in perspective}

The implications of the energy crisis in its total world economic and technological context will be examined at the 16th Annual Canadian-American Seminar, University of Windsor, Windsor, Ont. In particular, the way in which this crisis has had an impact on Canadian-American relations will be examined. The seminar will encompass such related topics as environmentalist concerns which place restrictions on the growth of energy exploration, the existence of a seller's market for energy, the need for international political and economic guidelines for the allocation of energy resources, and finally, the speculations which have been made on alternative sources of energy.

The registration fee is $\$ 40$ and the dates are 14 - 15 November, 1974.

Canada is Australia's largest source of sawnwood: 212,-

093 cubic metres in the six months ended December

1973. / Participation filler by Brian Myers 